\title{
Frequent loss of the AXINI locus but absence of AXINI gene mutations in adenocarcinomas of the gastro-oesophageal junction with nuclear $\beta$-catenin expression
}

\section{LB Koppert ${ }^{1,2,5}$, AW van der Velden ${ }^{1,5}, M$ van de $W^{2}$ tering $^{3}$, M Abbou', AMW van den Ouweland ${ }^{4}$, HW Tilanus ${ }^{2}$, BPL Wijnhoven ${ }^{2}$ and WNM Dinjens*,1}

'Department of Pathology, Josephine Nefkens Institute, Erasmus University Medical Center, Rotterdam, The Netherlands; ${ }^{2}$ Department of Surgery, Erasmus University Medical Center, Rotterdam, The Netherlands; ${ }^{3}$ Hubrecht Laboratory, Center for Biomedical Genetics, Utrecht, The Netherlands;

${ }^{4}$ Department of Clinical Genetics, Erasmus University Medical Center, Rotterdam, The Netherlands

Up to $60 \%$ of gastro-oesophageal junction (GEJ) adenocarcinomas show nuclear $\beta$-catenin expression, pointing to activated T-cell factor (TCF)/ $\beta$-catenin-driven gene transcription. We demonstrate in five human GEJ adenocarcinoma cell lines that nuclear $\beta$ catenin expression indeed correlates with enhanced TCF-mediated transcription of a reporter gene. In several tumour types, TCF/ $\beta$ catenin activation is caused by mutations in either adenomatous polyposis coli (APC), $\beta$-catenin exon $3, A X I N I$, AXIN2 or $\beta$-transducin repeat-containing protein ( $\beta$ - $\operatorname{TrCP})$. In GEJ adenocarcinomas, very few APC and $\beta$-catenin mutations have been found. Therefore, the mechanism of Wnt pathway activation remains unclear. In the present study, we did not find AXINI gene mutations in 17 GEJ tumours with nuclear $\beta$-catenin expression (without $\beta$-catenin exon 3 mutations). Six intragenic single nucleotide polymorphisms (SNPs) were identified. One of these, the AXINI gene TI942C SNP, has a frequency of $21 \%$ but is only very recently described despite numerous AXINI gene mutational studies. We provide evidence why this SNP was missed in single strand conformation polymorphism analyses. The AXINI gene G2063A variation was previously described as a gene mutation but we demonstrate that this is a polymorphism. With these six SNPs loss of heterozygosity $(\mathrm{LOH})$ was found in II of I5 (73\%) informative tumours. To investigate a possible AXINI gene dosage effect in GEJ tumours expressing nuclear $\beta$-catenin, AXINI locus LOH was determined in 20 tumours expressing membranous and no nuclear $\beta$-catenin. $\mathrm{LOH}$ was found in 10 of $13(77 \%)$ informative cases. AXINI protein immunohistochemistry revealed cytoplasmic expression in all tumours irrespective of the presence of AXINI locus LOH. These data indicate that nuclear $\beta$-catenin expression is indicative for activated Wnt signalling and that neither AXINI gene mutations nor AXIN I locus LOH are involved in Wnt pathway activation in GEJ adenocarcinomas.

British Journal of Cancer (2004) 90, 892-899. doi: I0.1038/sj.bjc.660I589 www.bjcancer.com

(C) 2004 Cancer Research UK

Keywords: oesophageal cancer; Wnt signalling pathway; AXINI; mutation; loss of heterozygosity

The incidence of adenocarcinoma of the gastro-oesophageal junction (GEJ), that is, distal oesophagus and gastric cardia, is rising in the Western world (Blot et al, 1991; Powell and McConkey, 1992; Botterweck et al, 2000). Patients with GEJ adenocarcinoma have a poor prognosis with 5-year survival rates of less than 25\% (Tilanus et al, 1993). Despite the common occurrence of this malignancy, relatively little is known about the molecular mechanisms underlying the genesis and the progression of these tumours.

Numerous studies focused on cell-cell adhesion in GEJ adenocarcinomas since defective cell-cell adhesion is an important feature in epithelial tumour initiation and progression (Jankowski et al, 1997; Hirohashi, 1998; Nollet et al, 1999;

\footnotetext{
*Correspondence: Dr WNM Dinjens, Department of Pathology, Erasmus MC, Josephine Nefkens Institute, room BE 312a, PO Box 1738, 3000 DR Rotterdam, The Netherlands;

E-mail: w.dinjens@erasmusmc.nl

${ }^{5}$ These authors contributed equally to the work. LB Koppert is sponsored by the Dutch Cancer Society/KWF

Received 28 August 2003; accepted 23 November 2003
}

Wijnhoven et al, 2000a; Van Aken et al, 2001; Hajra and Fearon, 2002). Aberrant expression of components of the E-cadherincatenin complex, the prime mediator of epithelial cell-cell adhesion, has been found frequently in GEJ adenocarcinomas. In addition, E-cadherin-catenin complex aberrations appeared to have prognostic value in these tumours (Jian et al, 1997; Krishnadath et al, 1997; Bailey et al, 1998; Washington et al, 1998; Bian et al, 2000; Osterheld et al, 2002).

Recently, the E-cadherin-catenin complex component $\beta$ catenin has been demonstrated to play a dual role in the tumorigenic process (Korinek et al, 1997; Morin et al, 1997; Resnik, 1997; Rubinfeld et al, 1997; Bienz and Clevers, 2000; Polakis, 2000). $\beta$-Catenin, originally described to function in epithelial cell-cell adhesion, is implicated also in the Wnt signalling cascade as a transcriptional activator. In the absence of Wnt signals, $\beta$-catenin is located at the plasma membrane, linked to E-cadherin, and functions in cell-cell adhesion. Excess cytoplasmic $\beta$-catenin is sequestered in a protein complex comprised of adenomatous polyposis coli (APC), glycogen synthase kinase $3 \beta$ (GSK-3 $\beta$ ) and AXIN1 or AXIN2. In this complex, $\beta$-catenin is phosphorylated by GSK-3 $\beta$ and then targeted by $\beta$-transducin repeat-containing protein $(\beta-\operatorname{TrCP})$ to 
proteasomal degradation. Activated Wnt signalling inhibits the phosphorylation of $\beta$-catenin, thereby preventing its degradation. The impaired $\beta$-catenin degradation leads to an increase in cytoplasmic $\beta$-catenin and its translocation to the nucleus. Nuclear $\beta$-catenin forms heterodimers with members of the T-cell factor (TCF) family of transcription factors and activates genes containing TCP-binding sites (Bienz and Clevers, 2000; Polakis, 2000).

It has been demonstrated that $\beta$-catenin/TCF-activated gene transcription can induce neoplastic transformation (Aoki et al, 1999; Kolligs et al, 2002; Miyoshi et al, 2002), and the $\beta$-catenin/ TCF target genes comprise the oncogenes $c$-myc (He et al, 1998), cyclin D1 (Tetsu \& McCormick, 1999) and ITF-2 (Kolligs et al, 2002). Impaired degradation of $\beta$-catenin in tumours has been reported to be caused by inactivating mutations in APC, AXIN1, AXIN2 or $\beta-\operatorname{TrCP}$ or oncogenic mutations in $\beta$-catenin exon 3 (Kinzler and Vogelstein, 1996; Bienz and Clevers, 2000; Liu et al, 2000; Polakis, 2000; Satoh et al, 2000b; Gerstein et al, 2002; Hajra and Fearon, 2002; Taniguchi et al, 2002; Yokota et al, 2002). These mutations are in most cases mutually exclusive (Sparks et al, 1998; Huang et al, 2000; Gayet et al, 2001; Gerstein et al, 2002; Taniguchi et al, 2002; Yokota et al, 2002).

Several studies have reported nuclear $\beta$-catenin expression in up to $60 \%$ of GEJ adenocarcinomas (Bailey et al, 1998; Washington et al, 1998; Bian et al, 2000; Wijnhoven et al, 2000b; Osterheld et al, 2002). This nuclear expression of $\beta$-catenin can be regarded as an indication for activated, oncogenic, $\beta$-catenin/TCF transcription. However, mutation analysis of $A P C$ and $\beta$-catenin in GEJ adenocarcinomas revealed mutations in only less than 7 and $3 \%$ of cases respectively (Powell et al, 1994; Gonzalez et al, 1997; Bian et al, 2000; Choi et al, 2000). In accordance with these data, we recently did not find $\beta$-catenin exon 3 mutations in a series of 69 GEJ adenocarcinomas (Wijnhoven et al, 2000b). Inactivation of the AXIN1 gene has been demonstrated to induce $\beta$-catenin/TCF transcription, and AXIN1 gene mutations have been described in hepatocellular carcinomas, hepatoblastomas, colorectal cancers, ovarian endometrioid adenocarcinomas and in sporadic medulloblastomas (Satoh et al, 2000b; Webster et al, 2000a; Laurent-Puig et al, 2001; Dahmen et al, 2001b; Wu et al, 2001; Shimizu et al, 2002; Taniguchi et al, 2002; Yokota et al, 2002; Baeza et al, 2003; Miao et al, 2003). In addition, reduced protein expression of AXIN1 has recently been reported to correlate with tumour progression in oesophageal squamous cell carcinoma (Nakajima et al, 2003). These results prompted us to search for genomic aberrations in the AXIN1 gene in GEJ adenocarcinomas. From the previously investigated series of 69 GEJ adenocarcinomas, 17 tumours with prominent nuclear $\beta$-catenin expression were selected for mutation and loss of heterozygosity (LOH) analysis. The entire coding region including the exon-intron boundaries of the AXIN1 gene was analysed for genetic alterations by single strand conformation polymorphism (SSCP) analysis. The presence of six intragenic single nucleotide polymorphisms (SNPs) was used to detect LOH. These six SNPs were also used to perform AXIN1 gene LOH analysis in 20 tumours with strong membranous $\beta$-catenin expression. In addition, AXIN1 protein expression was investigated by immunohistochemistry in all 37 tumour samples.

\section{MATERIALS AND METHODS}

\section{$\mathrm{TCF} / \boldsymbol{\beta}$-catenin reporter gene assay}

All cell lines, JROECL19, JROEL33, SKGT-4, TE-7, OACP4C and SW480, were cultured in RPMI 1640 supplemented with $10 \%$ fetal calf serum and antibiotics. Transcriptional activation mediated by $\mathrm{TCF} / \beta$-catenin protein complexes was determined by transient transfection of the cell lines with either the pTOPGLOW or pFOPGLOW reporter constructs as described previously (van de Wetering et al, 2001). The pTOPGLOW and pFOPGLOW constructs contain a multimerized wild-type or mutant TCF binding motive, respectively, upstream of a luciferase gene. Cells were grown to $50-80 \%$ confluency in six-well plates and transfection was performed with $1 \mu \mathrm{g}$ of purified constructs each, using Fugene-6 (Boehringer, Mannheim, Germany). Transfection efficiencies were determined by cotransfection of a pRL-TK reporter construct (Promega, Madison, WI, USA) that contained the Renilla luciferase gene under control of the herpes simplex virus thymidine kinase promoter. Cells were harvested $24 \mathrm{~h}$ after transfection. Activity of both luciferases was measured sequentially in each sample using the Dual-Luciferase Reporter Assay System (Promega, Madison, WI, USA). TCF-mediated gene transcription was defined by the ratio of pTOPGLOW to pFOPGLOW luciferase activities. The luciferase activity of the internal control reporter was used to correct for differences in transfection efficiency.

\section{Tumour and cell line DNA samples}

In a previous study of $69 \mathrm{GEJ}$ adenocarcinoma samples consisting of 54 primary tumours, four lymph node metastases, nine xenografts and two in vitro cell lines were investigated for $\beta$ catenin expression and $\beta$-catenin exon 3 mutations (Wijnhoven et al, 2000b). From all cases, tumour and normal DNA was isolated from frozen samples by standard proteinase $\mathrm{K}$ digestion and phenol/chloroform extraction. After $\beta$-catenin immunohistochemistry on $5 \mu \mathrm{m}$ paraffin sections, parts of the tumour with intense nuclear reactivity were isolated by microdissection from consecutive unstained sections. From the microdissected fragments, DNA was isolated with standard proteinase $\mathrm{K}$ digestion followed by phenol/chloroform extraction and ethanol precipitation. No $\beta$-catenin exon 3 aberrations were found in these samples. For the present study, the DNA from 17 tumours with strong nuclear $\beta$-catenin expression was used. Fifteen samples were originated from primary GEJ adenocarcinomas and two were from GEJ adenocarcinoma-derived cell lines JROECL19 and JROECL33 (Rockett et al, 1997). In addition, the DNAs from 20 tumours with strong membranous $\beta$-catenin expression were investigated for $\mathrm{LOH}$ with the six SNPs. These 20 samples comprised 17 primary tumours and the established cell lines OACP4C, SKGT-4 and TE-7 (Altorki et al, 1993; Nishihira et al, 1993; de Both et al, 2001). Cell lines JROECL19 and 33 were obtained from the European Collection of Cell Cultures (ECACC, Wiltshire, UK), SKGT-4 and TE-7 were kind gifts from D Schrump, NIH, Bethesda, USA and T Kudo, Tohoku University, Sendai, Japan, respectively; OACP4C was established at our own institute. From cell lines JROECL19 and JROECL33, patient's normal tissue was kindly provided by Dr SJ Darnton, Birmingham Heartlands Hospital, Birmingham, UK. From cell line OACP4C patient's normal tissue was obtained from our pathology archive, and from cell lines SKGT-4 and TE-7 patient's normal tissue was not available. To determine SNP frequencies in the normal population, we used DNA isolated from 161 healthy Caucasian blood donor volunteers.

\section{Mutation analysis of the AXIN1 gene}

The 17 pairs of tumour and normal DNA from tumours with nuclear $\beta$-catenin expression were screened for aberrations in the AXIN1 gene. The entire coding sequence, including the exonintron boundaries, was investigated by PCR-SSCP using the previously described 23 sets of primers with slight modifications (Lin et al, 2000). All amplifications were performed in $15 \mu \mathrm{l} \mathrm{PCR}$ containing 50-100 ng DNA, $1.5 \mathrm{mM} \mathrm{MgCl}_{2}, 0.02 \mathrm{~mm}$ dATP, $0.2 \mathrm{~mm}$ dGTP, dCTP and dTTP each, $0.8 \mu \mathrm{Ci}$ of $\left[{ }^{32} \mathrm{P}\right] \mathrm{dATP}$ (Amersham Biosciences, Buckinghamshire, UK), 20 pmol of each primer and $0.3 \mathrm{U}$ AmpliTaq Gold polymerase (Perkin-Elmer Applied Biosystems, Foster City, CA, USA). AmpliTaq Gold polymerase was used because this enzyme is superior to other DNA polymerases with regard to amplification of DNA retrieved from routine 
formalin-fixed and paraffin-embedded tissues. To the PCRs with primer sets $4,10,12,13,14,15,18,21$ and 23, DMSO (5\%) was added to increase the amplification efficiency. The PCRs were performed with a hotstart of $95^{\circ} \mathrm{C}$ for $5 \mathrm{~min}$ followed by 35 cycles of $95^{\circ} \mathrm{C}$ for $30 \mathrm{~s}, 55^{\circ} \mathrm{C}$ (primer sets 10 and 14 at 58 and $60^{\circ} \mathrm{C}$, respectively) for $45 \mathrm{~s}$ and $72^{\circ} \mathrm{C}$ for $45 \mathrm{~s}$ and ended up with an extension step of $72^{\circ} \mathrm{C}$ for $10 \mathrm{~min}$. The PCR products were diluted $1: 4$ with loading buffer (95\% formamide, $10 \mathrm{~mm}$ EDTA, 0.05\% bromophenol blue and $0.05 \%$ xylene cyanol), heated for $5 \mathrm{~min}$, cooled on ice and electrophoresed in $6 \%$ polyacrylamide gels containing $10 \%$ glycerol at $7 \mathrm{~W}$ overnight at room temperature, in $1 \times \mathrm{TBE}$ running buffer. Gels were dried and exposed to X-ray films at $-80^{\circ} \mathrm{C}$. Results were evaluated by visual inspection. With the used SSCP conditions, the PCR products from primer sets 18, 19 and 21 resulted in simple banding patterns, inefficient for the detection of aberrations. To increase the DNA aberration detection efficiency, these PCR products were electrophoresed without glycerol at $4{ }^{\circ} \mathrm{C}$ for $6 \mathrm{~h}$ resulting in more complex banding patterns. For each variant SSCP pattern identified by SSCP analysis, the genomic DNA samples were reamplified for bidirectional direct sequencing with the amplification primers. In 20 DNA samples from tumours with strong membranous $\beta$-catenin expression, LOH was determined by SSCP analysis of six detected SNPs. These SNPs are at positions (according to GenBank accession no. AF009674) A94C, C874T, intron 4+17 G $\rightarrow$ A (nucleotide position identified from exon-intron boundary), G1396A, T1942C and G2063A. Amplification of these SNPs was performed with primer sets $1,7,11,12$ and 17 , respectively.

\section{$\beta$-Catenin and AXIN1 immunohistochemistry}

In all 37 tumour samples, immunostaining for $\beta$-catenin and AXIN1 was performed on $5 \mu \mathrm{m}$ paraffin sections with a mouse anti-human $\beta$-catenin monoclonal antibody (Transduction Laboratories, Lexington, KY, USA; $1: 200,30 \mathrm{~min}$, room temperature) (Wijnhoven et al, 2000b) and a rabbit polyclonal anti-human AXIN1 antibody
(Zymed Laboratories, San Francisco, CA, USA; 1:25, 30 min, room temperature), respectively. After deparaffinisation and treatment with methanol/ $\mathrm{H}_{2} \mathrm{O}_{2}$, antigen retrieval was performed in citrate buffer for $15 \mathrm{~min}$ prior to incubation with the $\beta$-catenin antibody. No antigen retrieval was necessary for the AXIN1 immunohistochemistry. Immunoreactivity was made visible by a standard avidin biotin immunoperoxidase technique, using a commercially available kit (Labvision, Fremont, CA, USA) and diaminobenzidine hydrochloride (Fluka, Neu-Ulm, Germany). As negative controls, normal mouse immunoglobulins and normal rabbit serum were used.

\section{RESULTS}

\section{$\mathrm{TCF} / \beta$-catenin reporter gene assay}

The TCF/ $\beta$-catenin reporter gene assay was performed with the pTOPGLOW and pFOPGLOW constructs. Cell lines JROECL19 and JROECL33, both with nuclear $\beta$-catenin expression (JROECL19, Figure 1C), showed 350 - and 18-fold increase in transcriptional activity of the pTOPGLOW reporter as compared to the negative control pFOPGLOW (Figure 2). Cell lines SKGT-4, TE-7 and $\mathrm{OACP} 4 \mathrm{C}$, all with membranous $\beta$-catenin immunoreactivity (TE-7, Figure 1D), showed no enhanced transcription of the pTOPGLOW reporter (Figure 2).

\section{Mutation analysis of the AXIN1 gene}

SSCP analysis of the AXIN1 gene in 17 tumour/normal DNA pairs from tumours with strong nuclear $\beta$-catenin expression (Figure $1 \mathrm{~A}, \mathrm{C})$ revealed six different aberration patterns. All these aberrations were also present in the corresponding normal DNA. Sequencing of the aberrant samples identified six different SNPs. These were at positions (according to GenBank accession no. AF009674) A94C, C874T, intron 4+17 G $\rightarrow$ A, G1396A, T1942C and G2063A (Figure 3).

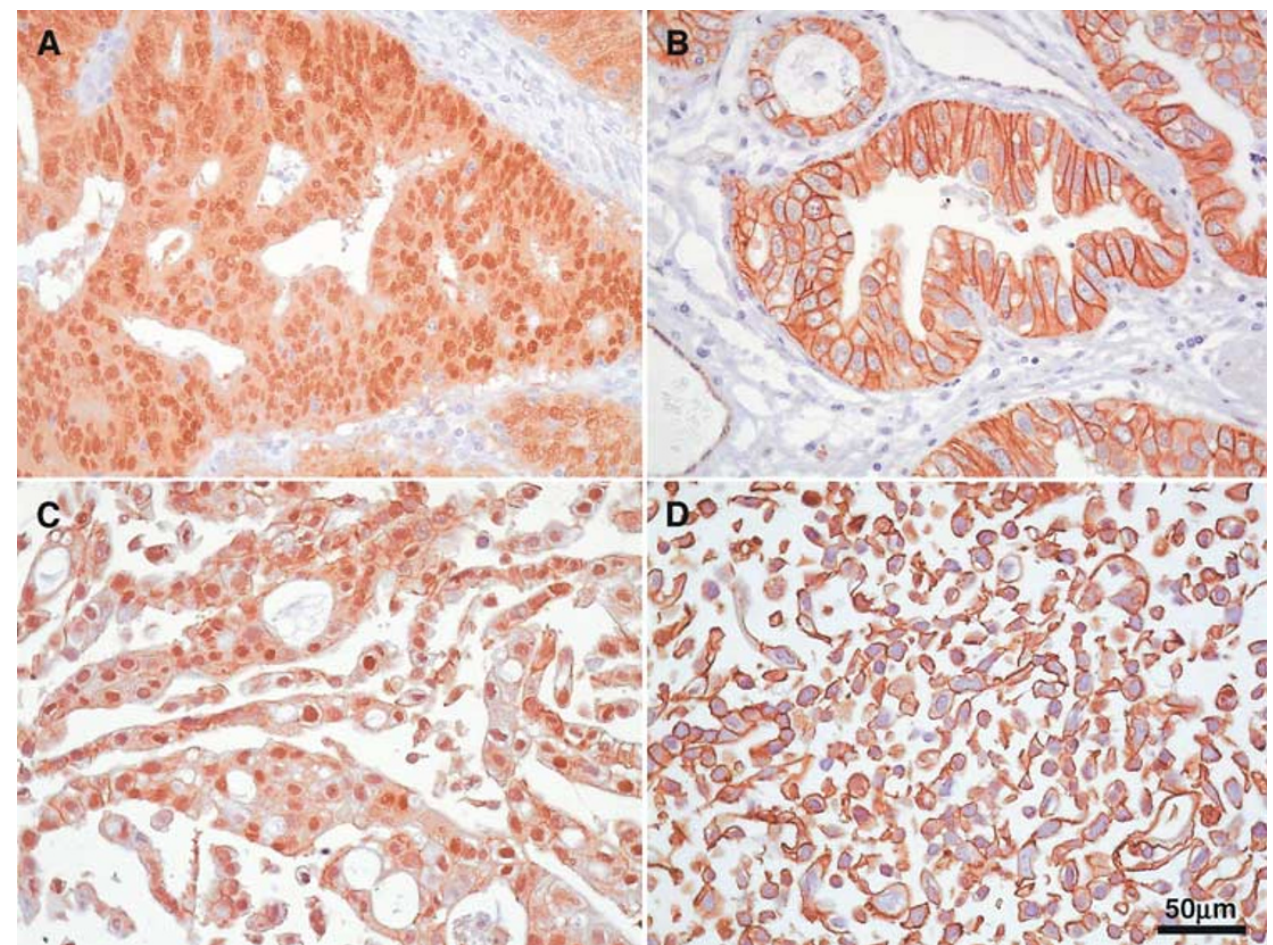

Figure I Immunohistochemistry of $\beta$-catenin in GEJ adenocarcinomas and cell lines ( $\beta$-catenin antibody, DAB and haematoxylin counterstain, magnification $\times 400)$. (A) GEJ adenocarcinoma. Strong nuclear expression of $\beta$-catenin in the tumour cells. (B) GEJ adenocarcinoma. Prominent membranous expression of $\beta$-catenin. (C) Cell line JROECL 19. Strong nuclear expression of $\beta$-catenin. (D) Cell line TE-7. Membranous expression of $\beta$ catenin. 
Of the 17 cases, 15 appeared to be heterozygous for at least one polymorphism and $\mathrm{LOH}$ was observed in $11(73 \%)$ cases (Table 1). The polymorphisms were used to investigate $\mathrm{LOH}$ in $20 \mathrm{GEJ}$ adenocarcinoma cases with strong membranous $\beta$-catenin expression (Figure 1B, D). Also in this series, all six polymorphisms were present and in 10 of 13 (77\%) informative cases LOH was found (Table 2).

The T1942C and G2063A SNPs were found to have population frequencies of 21 and 3\%, respectively (Tables 1 and 2). The relatively frequent SNP T1942C was only described very recently in two independent studies (Baeza et al, 2003; Miao et al, 2003) and remained undetected in 10 AXIN1 gene mutation studies (Lin et al, 2000; Satoh et al, 2000a; Webster et al, 2000b; Dahmen et al, 2001a; Wu et al, 2001; Miao et al, 2002; Shimizu et al, 2002; Taniguchi et al, 2002; Yokota et al, 2002; Nakajima et al, 2003). In most of these studies, as in ours, SSCP analyses were used. To determine whether the SSCP conditions have influence on the detection of the T1942C SNP, we amplified DNA samples with AmpliTaq Gold and with Promega Taq DNA polymerases (Promega, Madison, WI, USA) in both AmpliTaq Gold and Promega Taq buffers. The AmpliTaq Gold buffer consists of $15 \mathrm{~mm}$ Tris- $\mathrm{HCl}(\mathrm{pH}$ 8.0), $50 \mathrm{~mm} \mathrm{KCl}$ and $1.5 \mathrm{~mm} \mathrm{MgCl}_{2}$ and the Promega buffer consists of $10 \mathrm{~mm}$ Tris $-\mathrm{HCl}(\mathrm{pH} 9.0), 50 \mathrm{~mm} \mathrm{KCl}, 1.5 \mathrm{~mm} \mathrm{MgCl}_{2}$ and $0.1 \%$

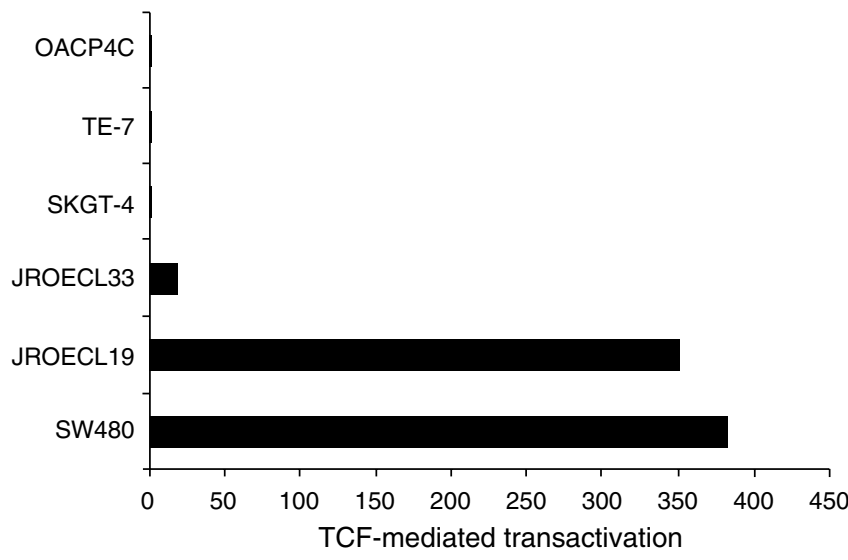

Figure 2 TCF-mediated transcriptional activation in GEJ adenocarcinoma cell lines. Constitutive transcriptional activation was detected in cell lines JROECL33 and JROECL 19. APC mutant colorectal cancer cell line SW480 served as a positive control. TCF-mediated transcriptional activity was defined as the ratio of PTOPGLOW:pFOPGLOW luciferase activities, each corrected for $\mathrm{PRL}$-TK luciferase activities and where no transactivation equals $\mathrm{I}$.
Triton X-100. As demonstrated in Figure 4, the T1942C SNP is only clearly visible after amplification with the AmpliTaq buffer.

\section{$\beta$-Catenin and AXIN1 immunohistochemistry}

As mentioned before, 37 GEJ adenocarcinoma samples were investigated, 17 with strong nuclear $\beta$-catenin expression and 20 cases with normal membranous reactivity (Figure 1). Eleven of the
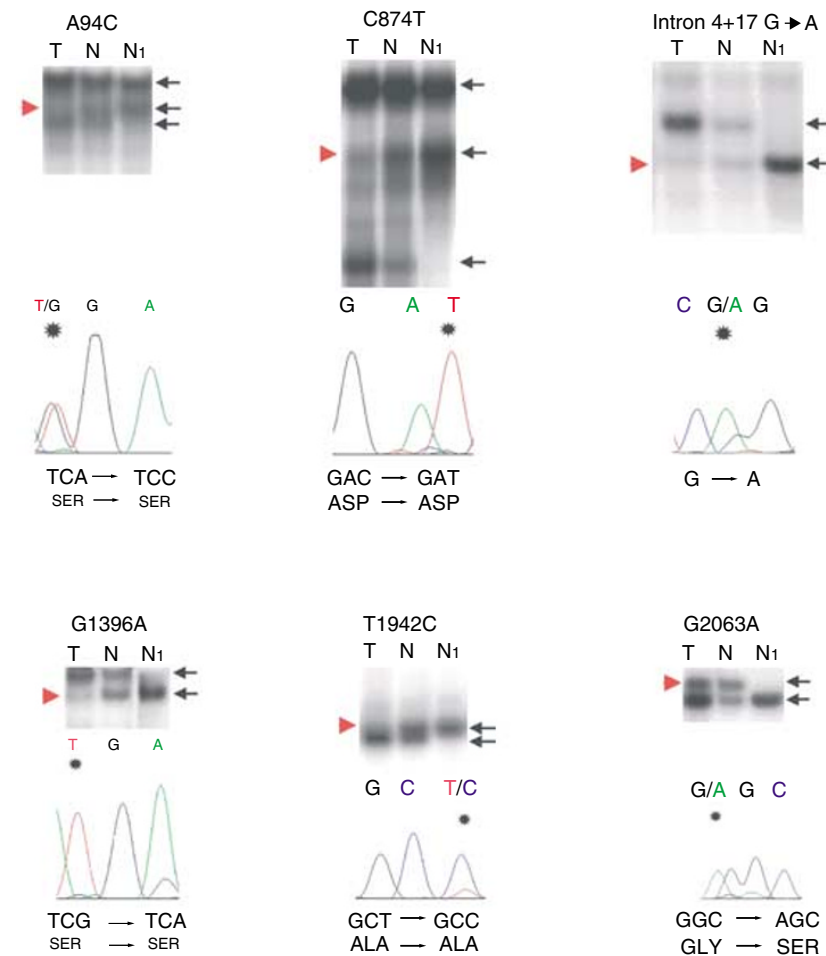

Figure 3 PCR-SSCP and sequencing analyses of the SNPs in tumours (T) and corresponding normal DNA $(\mathrm{N})$, compared with DNA from individuals without SNPS (NI). Informative cases with $\mathrm{LOH}$ are shown. Black arrows point to allelic patterns. Red arrow heads point to deleted alleles in the tumour DNA. The sequencing chromatograms below each autoradiograph show the alterations (note the substituted nucleotide marked by an asterisk), which all represent SNPs. SNPs A94C and GI396A are annotated in the reverse complementary direction, whereas the SNPs C874T, intron $4+17 \mathrm{G} \rightarrow \mathrm{A}, \mathrm{T} 1942 \mathrm{C}$ and G2063A are annotated in the forward direction.

Table I Patterns of allelic loss in GEJ adenocarcinomas with nuclear B-catenin expression

\begin{tabular}{|c|c|c|c|c|c|c|}
\hline Case & A94C & C874T & Intron $4+17 \mathbf{G} \rightarrow \mathbf{A}$ & GI396A & TI942C & G2063A \\
\hline I & Loss & $\mathrm{HN}$ & Loss & $\mathrm{HN}$ & $\mathrm{HN}$ & $\mathrm{HN}$ \\
\hline 2 & $\mathrm{HN}$ & No loss & $\mathrm{HN}$ & No loss & Loss & $\mathrm{HN}$ \\
\hline 3 & $\mathrm{HN}$ & $H N$ & $\mathrm{HN}$ & $H N$ & $\mathrm{HN}$ & $\mathrm{HN}$ \\
\hline 4 & $H P$ & $\mathrm{HN}$ & Loss & $\mathrm{HN}$ & $\mathrm{HN}$ & $\mathrm{HN}$ \\
\hline 5 & Loss & $\mathrm{HN}$ & $\mathrm{HN}$ & $\mathrm{HN}$ & $\mathrm{HN}$ & $\mathrm{HN}$ \\
\hline 6 & $\mathrm{HN}$ & $\mathrm{HP}$ & $\mathrm{HN}$ & No loss & $\mathrm{HN}$ & $\mathrm{HN}$ \\
\hline 7 & $\mathrm{HN}$ & $\mathrm{HP}$ & $\mathrm{HN}$ & No loss & $\mathrm{HN}$ & $\mathrm{HN}$ \\
\hline 8 & Loss & $\mathrm{HN}$ & Loss & No loss & No loss & $\mathrm{HN}$ \\
\hline 9 & $\mathrm{HN}$ & Loss & $\mathrm{HN}$ & $\mathrm{HN}$ & $H N$ & $\mathrm{HN}$ \\
\hline 10 & No loss & $\mathrm{HN}$ & No loss & No loss & $\mathrm{HN}$ & $\mathrm{HN}$ \\
\hline | | & $H N$ & $\mathrm{HN}$ & $\mathrm{HN}$ & $\mathrm{HN}$ & $\mathrm{HN}$ & $\mathrm{HN}$ \\
\hline 12 & $\mathrm{HN}$ & $\mathrm{HN}$ & $\mathrm{HN}$ & $\mathrm{HN}$ & $\mathrm{HN}$ & $\mathrm{HN}$ \\
\hline 13 & $\mathrm{HN}$ & $\mathrm{HN}$ & $\mathrm{HN}$ & Loss & Loss & $\mathrm{HN}$ \\
\hline 14 & $\mathrm{HN}$ & $\mathrm{HN}$ & $\mathrm{HN}$ & Loss & $\mathrm{HN}$ & $\mathrm{HN}$ \\
\hline 15 & $\mathrm{HN}$ & Loss & $\mathrm{HN}$ & Loss & $\mathrm{HN}$ & $\mathrm{HN}$ \\
\hline Frequency & $6 / 34(18 \%)$ & $8 / 34$ (24\%) & $4 / 34(12 \%)$ & $9 / 34(26 \%)$ & $4 / 34(12 \%)$ & I/34 (3\%) \\
\hline Frequency NP & ND & ND & ND & ND & $69 / 322(21 \%)$ & $9 / 322(3 \%)$ \\
\hline
\end{tabular}

$\mathrm{HN}=$ homozygous normal; $\mathrm{HP}=$ homozygous polymorphism; $\mathrm{NP}=$ normal population; $\mathrm{ND}=$ no data. 
Table 2 Patterns of allelic loss in GEJ adenocarcinomas without nuclear ß-catenin expression

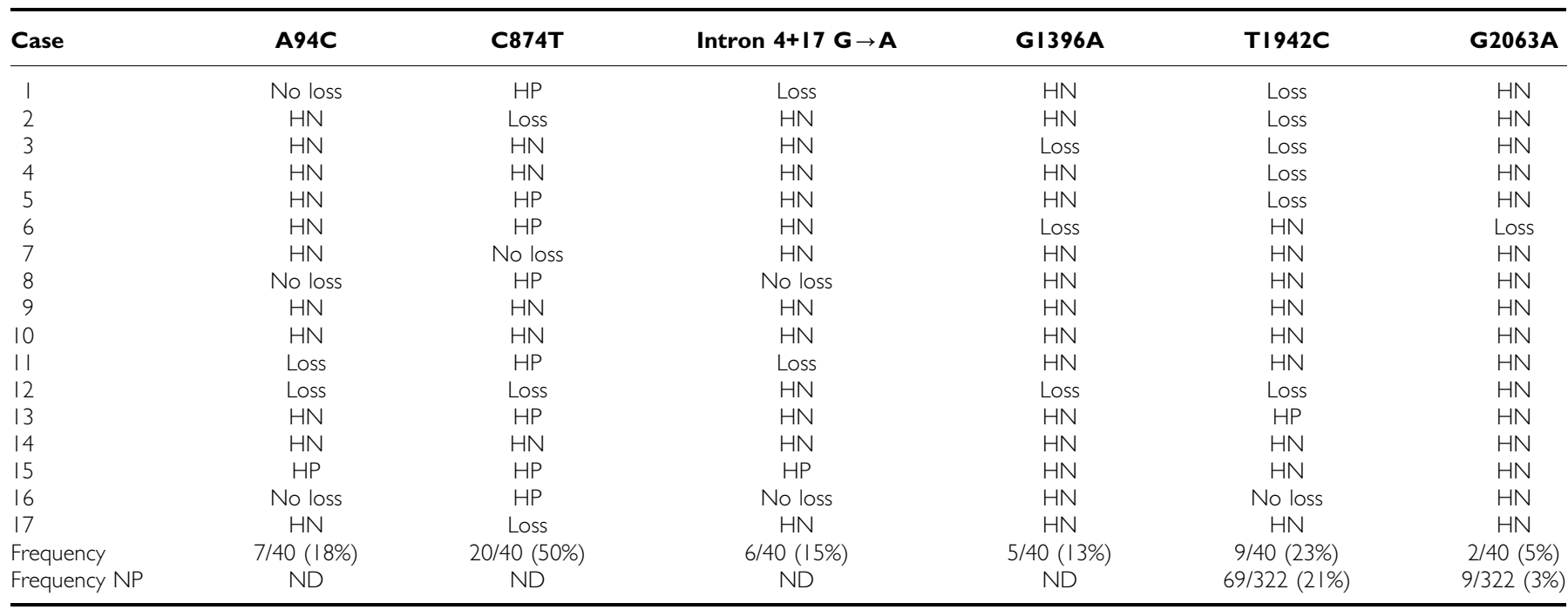

For abbreviations see Table | footnote.

A

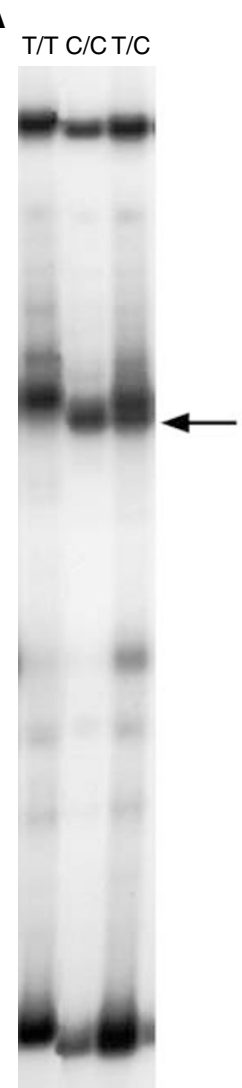

B

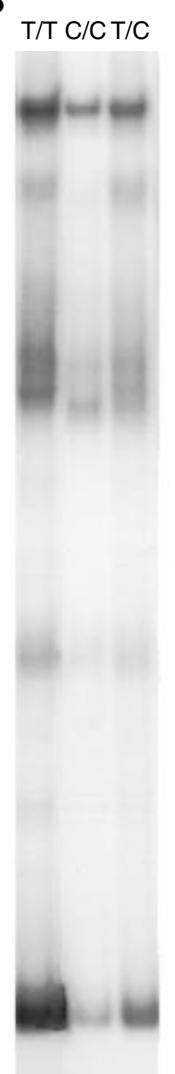

C

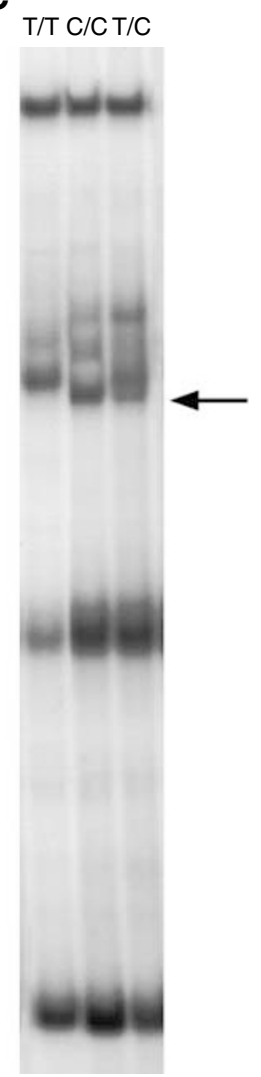

Figure 4 TI942C PCR-SSCP. Three DNA samples, 1942T/T (homozygous normal), 1942C/C (homozygous polymorphic), 1942T/C (heterozygous), were amplified with AmpliTaq Gold polymerase and AmpliTaq Gold buffer (A), Promega Taq and Promega buffer (B), Promega Taq and AmpliTaq Gold buffer $(\mathbf{C})$ and with AmpliTaq Gold and Promega buffer (no PCR products obtained). All samples were amplified and SSCPelectrophoresed in the same experiment. Arrows point to the polymorphic SSCP fragment. Note that the polymorphic fragments are clearly visible only after amplification in AmpliTaq Gold buffer $(\mathbf{A}, \mathbf{C})$.

$15(73 \%)$ informative cases with nuclear $\beta$-catenin expression and 10 of $13(77 \%)$ informative cases with membranous $\beta$-catenin immunoreactivity showed loss of the AXIN1 gene locus. In all

tumour samples AXIN1 protein expression was confined to the cytoplasm of the tumour cells exclusively (Figure 5). No consistent differences in AXIN1 protein expression were observed between tumours with and without AXIN1 locus loss, irrespective of nuclear or membranous $\beta$-catenin expression (Figure 5).

\section{DISCUSSION}

Nuclear $\beta$-catenin expression has been reported in up to $60 \%$ of GEJ adenocarcinomas (Bailey et al, 1998; Washington et al, 1998; Bian et al, 2000; Wijnhoven et al, 2000b; Osterheld et al, 2002). In the present study, we used the nuclear expression of $\beta$ catenin in GEJ adenocarcinomas as an indication for activated Wnt signalling. This presupposition is substantiated by our finding of highly enhanced TCF-mediated transcriptional activity in the cell lines JROECL19 and JROECL33, both with nuclear $\beta$-catenin expression. None of the three cell lines without nuclear but with membranous $\beta$-catenin expression had increased transcription of the TOPGLOW reporter. Activated Wnt signalling in tumours is caused by increased levels of $\beta$-catenin, which can be the result of mutations in APC, $\beta$-catenin, AXIN1, AXIN2 or $\beta$-TrCP (Kinzler and Vogelstein, 1996; Bienz and Clevers, 2000; Liu et al, 2000; Polakis, 2000; Satoh et al, 2000b; Gerstein et al, 2002; Hajra and Fearon, 2002; Taniguchi et al, 2002; Yokota et al, 2002). To date only APC and $\beta$-catenin mutation analysis in GEJ adenocarcinomas has been performed and only few mutations were found (Powell et al, 1994; Gonzalez et al, 1997; Bian et al, 2000; Choi et al, 2000; Wijnhoven et al, 2000b). Therefore, the mechanism of Wnt activation remains obscure in these tumours. These results prompted us to investigate GEJ adenocarcinoma samples with nuclear $\beta$-catenin expression for mutations in the AXIN1 gene. None of the tumours in the present study showed $\beta$-catenin exon 3 mutations (Wijnhoven et al, 2000b). In $17 \mathrm{GEJ}$ adenocarcinoma samples, no AXIN1 gene mutations were found. We therefore conclude that Wnt activation in GEJ tumours is not caused by AXIN1 gene mutations.

Six previously described polymorphisms in the AXIN1 gene were detected. All the detected DNA variations were also found in patients' constitutional DNAs indicating that they are truly polymorphisms and not somatic mutations. The G2063A SNP in exon 6 results in a substitution from glycine to serine. This polymorphism is described by Webster et al (2000a), although these authors annotated the polymorphism to exon 7 and regarded 

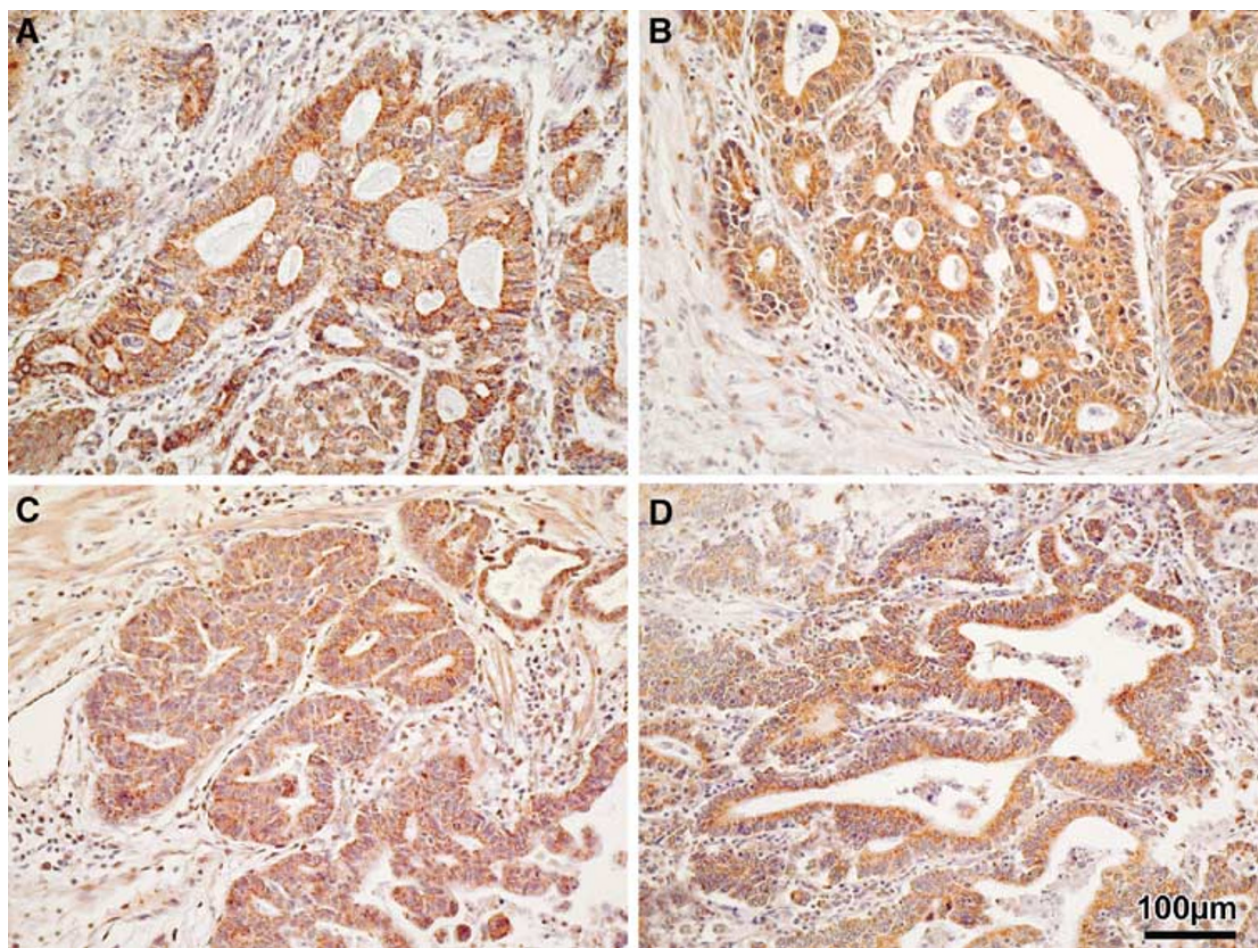

Figure 5 Immunohistochemistry of AXINI in GEJ adenocarcinomas (AXINI antibody, DAB and haematoxylin counterstain, magnification $\times 200)$. $(\mathbf{A}, \mathbf{B})$ GEJ adenocarcinomas with nuclear $\beta$-catenin expression without $(\mathbf{A})$ and with (B) AXIN / locus LOH. (C, D) GEJ adenocarcinomas with membranous $\beta$ catenin expression without $(\mathbf{C})$ and with $(\mathbf{D})$ AXINI locus LOH. Note the strong cytoplasmic AXINI expression in the tumour cells in all four cases.

it as a silent polymorphism. Furthermore, in a recent study by Taniguchi et al (2002), the G2063A polymorphism is found in one hepatocellular carcinoma and in one hepatoblastoma. Patients' normal tissues were not investigated and because the SNP was not found in their 147 control individuals, they regarded it as an AXIN1 mutation. We found a G2063A allele frequency of 4 and 3\% in GEJ adenocarcinoma patients and healthy controls, respectively, indicating that this AXIN1 gene variant is an SNP and not a mutation. In addition, we found a silent T1942C SNP (ala-ala) in exon 6 with an allele frequency of 18 and $21 \%$ in GEJ adenocarcinoma patients and healthy controls, respectively. This frequent SNP was only recently described, with comparable allele frequencies, in two independent studies (Baeza et al, 2003; Miao et $a l, 2003)$ and remained undetected in 10 AXIN1 gene mutation investigations within total 670 DNA samples (Lin et al, 2000; Satoh et al, 2000b; Webster et al, 2000b; Dahmen et al, 2001a; Wu et al, 2001; Miao et al, 2002; Shimizu et al, 2002; Taniguchi et al, 2002; Yokota et al, 2002; Nakajima et al, 2003). We demonstrate that detection of the T1942C SNP by SSCP analysis is influenced by the PCR buffer characteristics. This finding suggests that also other SSCP parameters (gel composition, running buffer, running temperature, etc) can have influence on the SNP detection.

The AXIN1 gene polymorphisms were used to determine LOH. Fifteen of 17 cases with nuclear $\beta$-catenin expression appeared to be heterozygous for at least one polymorphism, and from these in 11 (73\%) clear LOH was observed. This frequent loss of the AXIN1 gene could point to a dosage effect where the presence of $50 \%$ of the AXIN1 protein is insufficient for proper $\beta$-catenin degradation and subsequently leads to Wnt activation. To gather more information about this possibility, we investigated AXIN1 gene $\mathrm{LOH}$ with the detected SNPs in a series of 20 tumours from our previous study with strong, normal membranous $\beta$-catenin expression. These included three cell lines (OACP4C, SKGT-4 and TE-7) without enhanced TCF-mediated transcriptional activity. In this series, the T1942C and G2063A SNPs were detected in four and two samples, respectively. A total of 13 cases were informative and in $10(77 \%)$ clear LOH was observed.

By AXIN1 immunohistochemistry, no differences were observed between tumours with and without AXIN1 locus loss. It is known that with the semiquantitative immunohistochemical method a two-fold reduction in protein expression cannot be detected. In oesophageal squamous cell carcinoma, reduced protein and RNA expression has recently been described by Nakajima et al (2003). These investigators suggest AXIN1 gene silencing by promotor methylation, in addition to allelic losses, as a mechanism for AXIN1 downregulation. Our immunohistochemical results indicate that AXIN1 gene silencing does not occur in GEJ adenocarcinomas.

All the above-mentioned results indicate that AXIN1 gene haploinsufficiency is not sufficient for Wnt activation. This is in accordance with studies that demonstrated biallelic inactivation of the AXIN1 gene in several tumour types (Satoh et al, 2000b; Laurent-Puig et al, 2001; Taniguchi et al, 2002; Yokota et al, 2002), although heterozygous AXIN1 gene inactivation has also been described (Dahmen et al, 2001b; Webster et al, 2000a). Chromosome $16 \mathrm{p}$ loss has been reported in up to $40 \%$ in GEJ adenocarcinomas (Gleeson et al, 1998) and the presence of a tumour suppressor gene on $16 \mathrm{p} 13.3$ has been suggested by Takamochi et al (2001). The frequent AXIN1 locus LOH in our study could point to a gene dosage effect independent of Wnt pathway activation. Furthermore, it cannot be excluded that an as yet to be defined tumour suppressor gene on 16p13.3 is the actual target for LOH in GEJ adenocarcinomas.

Since mutations in $A P C, \beta$-catenin and AXIN1 do not play a major role in the frequent $\mathrm{TCF} / \beta$-catenin activation in GEJ adenocarcinomas, other components should be considered. AXIN2 gene mutations have been described in 11 colorectal cancers (Liu et al, 2000), one endometrioid ovarian adenocarcinoma (Wu et al, 2001) and two hepatocellular carcinomas (Taniguchi et al, 2002). Of these 14 tumour samples, 12 had nuclear $\beta$-catenin expression 
indicating activated Wnt signalling. The AXIN2 gene mutations appear to be present exclusively in tumours with a microsatellite instable phenotype since all AXIN2 mutant colorectal carcinomas and the ovarian endometrioid adencarcinoma were microsatellite instable (Wu et al, 2001; Taniguchi et al, 2002). The AXIN2 gene is an improbable candidate for Wnt activation in GEJ adenocarcinomas because microsatellite instability has been described in only less than 6\% in these tumours (Gleeson et al, 1996; Wijnhoven et al, $2000 \mathrm{~b})$. Another candidate is $\beta-\operatorname{Tr} C P$, involved in $\beta$-catenin degradation. Recently, $\beta$-TrCP mutations have been described in two prostate cancer samples, of which one had nuclear $\beta$-catenin expression (Gerstein et al, 2002).

Activated Wnt signalling can also be the result of activation of the canonical Wnt pathway by secreted Wnts or by expression of the Wnt receptors frizzled (Tanaka et al, 1998; Mizushima et al, 2002). In cell line cultures, this would imply the presence of an autocrine Wnt/frizzled loop. Furthermore, tumour necrosis factor$\alpha$ has recently been demonstrated to induce $\mathrm{TCF} / \beta$-catenin- mediated transcription in a GEJ adenocarcinoma cell line (Tselepis et al, 2002). These findings indicate that next to mutational activation of the Wnt pathway, gene expression alterations should be considered also as driving force behind Wnt activation in GEJ adenocarcinomas.

In summary, our results demonstrate that nuclear $\beta$-catenin expression in GEJ adenocarcinoma cell lines correlates with TCFmediated transcription activation and so with activated Wnt signalling. The frequent nuclear localisation of $\beta$-catenin in GEJ adenocarcinomas cannot be attributed by AXIN1 gene mutations. The mechanism of Wnt activation in these tumours remains to be established. In addition, the role of the frequent LOH of the AXIN1 locus in GEJ adenocarcinomas deserves further investigation.

\section{ACKNOWLEDGEMENT}

We acknowledge Frank van der Panne for photographic work.

\section{REFERENCES}

Altorki N, Schwartz GK, Blundell M, Davis BM, Kelsen DP, Albino AP (1993) Characterization of cell lines established from human gastricesophageal adenocarcinomas. Biologic phenotype and invasion potential. Cancer 72: 649-657

Aoki M, Hecht A, Kruse U, Kemler R, Vogt PK (1999) Nuclear endpoint of Wnt signaling: neoplastic transformation induced by transactivating lymphoid-enhancing factor 1. Proc Natl Acad Sci USA 96: 139-144

Baeza N, Masuoka J, Kleihues P, Ohgaki H (2003) AXIN1 mutations but not deletions in cerebellar medulloblastomas. Oncogene 22: 632-636

Bailey T, Biddlestone L, Shepherd N, Barr H, Warner P, Jankowski J (1998) Altered cadherin and catenin complexes in the Barrett's esophagus dysplasia-adenocarcinoma sequence: correlation with disease progression and dedifferentiation. Am J Pathol 152: $135-144$

Bian YS, Osterheld MC, Bosman FT, Fontolliet C, Benhattar J (2000) Nuclear accumulation of beta-catenin is a common and early event during neoplastic progression of Barrett esophagus. Am J Clin Pathol 114: $583-590$

Bienz M, Clevers H (2000) Linking colorectal cancer to Wnt signaling. Cell 103: $311-320$

Blot WJ, Devesa SS, Kneller RW, Fraumeni Jr JF (1991) Rising incidence of adenocarcinoma of the esophagus and gastric cardia. JAMA 265: $1287-1289$

Botterweck AA, Schouten LJ, Volovics A, Dorant E, van Den Brandt PA (2000) Trends in incidence of adenocarcinoma of the oesophagus and gastric cardia in ten European countries. Int J Epidemiol 29: 645 - 654

Choi YW, Heath EI, Heitmiller R, Forastiere AA, Wu TT (2000) Mutations in beta-catenin and APC genes are uncommon in esophageal and esophagogastric junction adenocarcinomas. Mod Pathol 13: 1055-1059

Dahmen RP, Koch A, Denkhaus D, Tonn JC, Sorensen N, Berthold F, Behrens J, Birchmeier W, Wiestler OD, Pietsch T (2001a) Deletions of AXIN1, a component of the WNT/wingless pathway, in sporadic medulloblastomas. Cancer Res 61: 7039-7043

Dahmen RP, Koch A, Denkhaus D, Tonn JC, Sorensen N, Berthold F, Behrens J, Birchmeier W, Wiestler OD, Pietsch T (2001b) Deletions of AXIN1, a component of the WNT/wingless pathway, in sporadic medulloblastomas. Cancer Res 61: 7039-7043

de Both NJ, Wijnhoven BP, Sleddens HF, Tilanus HW, Dinjens WN (2001) Establishment of cell lines from adenocarcinomas of the esophagus and gastric cardia growing in vivo and in vitro. Virchows Arch 438: 451 - 456

Gayet J, Zhou XP, Duval A, Rolland S, Hoang JM, Cottu P, Hamelin R (2001) Extensive characterization of genetic alterations in a series of human colorectal cancer cell lines. Oncogene 20: 5025-5032

Gerstein AV, Almeida TA, Zhao G, Chess E, Shih Ie M, Buhler K, Pienta K, Rubin MA, Vessella R, Papadopoulos N (2002) APC/CTNNB1 (betacatenin) pathway alterations in human prostate cancers. Genes Chromosomes Cancer 34: 9-16

Gleeson CM, Sloan JM, McGuigan JA, Ritchie AJ, Weber JL, Russell SE (1996) Ubiquitous somatic alterations at microsatellite alleles occur infrequently in Barrett's-associated esophageal adenocarcinoma. Cancer Res 56: $259-263$
Gleeson CM, Sloan JM, McGuigan JA, Ritchie AJ, Weber JL, Russell SE (1998) Barrett's oesophagus: microsatellite analysis provides evidence to support the proposed metaplasia-dysplasia-carcinoma sequence. Genes Chromosomes Cancer 21: 49-60

Gonzalez MV, Artimez ML, Rodrigo L, Lopez-Larrea C, Menendez MJ, Alvarez V, Perez R, Fresno MF, Perez MJ, Sampedro A, Coto E (1997) Mutation analysis of the p53, APC, and p16 genes in the Barrett's oesophagus, dysplasia, and adenocarcinoma. J Clin Pathol 50: 212-217

Hajra KM, Fearon ER (2002) Cadherin and catenin alterations in human cancer. Genes Chromosomes Cancer 34: 255-268

He TC, Sparks AB, Rago C, Hermeking H, Zawel L, da Costa LT, Morin PI, Vogelstein B, Kinzler KW (1998) Identification of c-MYC as a target of the APC pathway. Science 281: 1509-1512

Hirohashi S (1998) Inactivation of the E-cadherin-mediated cell adhesion system in human cancers. Am J Pathol 153: 333-339

Huang H, Mahler-Araujo BM, Sankila A, Chimelli L, Yonekawa Y, Kleihues P, Ohgaki H (2000) APC mutations in sporadic medulloblastomas. Am J Pathol 156: $433-457$

Jankowski JA, Bruton R, Shepherd N, Sanders DS (1997) Cadherin and catenin biology represent a global mechanism for epithelial cancer progression. Mol Pathol 50: 289-290

Jian WG, Darnton SJ, Jenner K, Billingham LJ, Matthews HR (1997) Expression of E-cadherin in oesophageal carcinomas from the UK and China: disparities in prognostic significance. J Clin Pathol 50: 640-644

Kinzler KW, Vogelstein B (1996) Lessons from hereditary colorectal cancer. Cell 87: $159-170$

Kolligs FT, Nieman MT, Winer I, Hu G, Van Mater D, Feng Y, Smith IM, Wu R, Zhai Y, Cho KR, Fearon ER (2002) ITF-2, a downstream target of the Wnt/TCF pathway, is activated in human cancers with beta-catenin defects and promotes neoplastic transformation. Cancer Cell 1: 145-155

Korinek V, Barker N, Morin PJ, van Wichen D, de Weger R, Kinzler KW, Vogelstein B, Clevers H (1997) Constitutive transcriptional activation by a beta-catenin-Tcf complex in APC-I- colon carcinoma. Science 275: $1784-1787$

Krishnadath KK, Tilanus HW, van Blankenstein M, Hop WC, Kremers ED, Dinjens WN, Bosman FT (1997) Reduced expression of the cadherincatenin complex in oesophageal adenocarcinoma correlates with poor prognosis. J Pathol 182: $331-338$

Laurent-Puig P, Legoix P, Bluteau O, Belghiti J, Franco D, Binot F, Monges G, Thomas G, Bioulac-Sage P, Zucman-Rossi J (2001) Genetic alterations associated with hepatocellular carcinomas define distinct pathways of hepatocarcinogenesis. Gastroenterology 120: 1763-1773

Lin YM, Kato T, Satoh S, Nakamura Y, Furukawa Y (2000) Identification of novel polymorphisms in the AXIN1++ and CDX-2 genes. J Hum Genet 45: $254-256$

Liu W, Dong X, Mai M, Seelan RS, Taniguchi K, Krishnadath KK, Halling KC, Cunningham JM, Boardman LA, Qian C, Christensen E, Schmidt SS, Roche PC, Smith DI, Thibodeau SN (2000) Mutations in AXIN2 cause colorectal cancer with defective mismatch repair by activating betacatenin/TCF signalling. Nat Genet 26: 146-147 
Miao J, Kusafuka T, Udatsu Y, Okada A (2002) Axin, the main component of the Wnt signaling pathway, is not mutated in kidney tumors in children. Int J Mol Med 9: 377-379

Miao J, Kusafuka T, Udatsu Y, Okada A (2003) Sequence variants of the Axin gene in hepatoblastoma. Hepatol Res 25: 174-179

Miyoshi K, Rosner A, Nozawa M, Byrd C, Morgan F, Landesman-Bollag E, Xu X, Seldin DC, Schmidt EV, Taketo MM, Robinson GW, Cardiff RD, Hennighausen L (2002) Activation of different Wnt/betacatenin signaling components in mammary epithelium induces transdifferentiation and the formation of pilar tumors. Oncogene 21: $5548-5556$

Mizushima T, Nakagawa H, Kamberov YG, Wilder EL, Klein PS, Rustgi AK (2002) Wnt-1 but not epidermal growth factor induces beta-catenin/Tcell factor-dependent transcription in esophageal cancer cells. Cancer Res 62: $277-282$

Morin PJ, Sparks AB, Korinek V, Barker N, Clevers H, Vogelstein B, Kinzler KW (1997) Activation of beta-catenin-Tcf signaling in colon cancer by mutations in beta-catenin or APC. Science 275: 1787-1790

Nakajima M, Fukuchi M, Miyazaki T, Masuda N, Kato H, Kuwano H (2003) Reduced expression of Axin correlates with tumour progression of oesophageal squamous cell carcinoma. Br J Cancer 88: 1734-1739

Nishihira T, Hashimoto Y, Katayama M, Mori S, Kuroki T (1993) Molecular and cellular features of esophageal cancer cells. J Cancer Res Clin Oncol 119: $441-449$

Nollet F, Berx G, van Roy F (1999) The role of the E-cadherin/catenin adhesion complex in the development and progression of cancer. Mol Cell Biol Res Commun 2: 77-85

Osterheld MC, Bian YS, Bosman FT, Benhattar J, Fontolliet C (2002) Betacatenin expression and its association with prognostic factors in adenocarcinoma developed in Barrett esophagus. Am J Clin Pathol 117: $451-456$

Polakis P (2000) Wnt signaling and cancer. Genes Dev 14: 1837 - 1851

Powell J, McConkey CC (1992) The rising trend in oesophageal adenocarcinoma and gastric cardia. Eur J Cancer Prev 1: 265-269

Powell SM, Papadopoulos N, Kinzler KW, Smolinski KN, Meltzer SJ (1994) APC gene mutations in the mutation cluster region are rare in esophageal cancers. Gastroenterology 107: $1759-1763$

Resnik E (1997) beta-Catenin - one player, two games. Nat Genet 16: 9-11

Rockett IC, Larkin K, Darnton SI, Morris AG, Matthews HR (1997) Five newly established oesophageal carcinoma cell lines: phenotypic and immunological characterization. Br J Cancer 75: $258-263$

Rubinfeld B, Robbins P, El-Gamil M, Albert I, Porfiri E, Polakis P. (1997) Stabilization of beta-catenin by genetic defects in melanoma cell lines. Science 275: $1790-1792$

Satoh S, Daigo Y, Furukawa Y, Kato T, Miwa N, Nishiwaki T, Kawasoe T, Ishiguro H, Fujita M, Tokino T, Sasaki Y, Imaoka S, Murata M, Shimano T, Yamaoka Y, Nakamura Y (2000a) AXIN1 mutations in hepatocellular carcinomas, and growth suppression in cancer cells by virus-mediated transfer of AXIN1. Nat Genet 24: 245-250

Satoh S, Daigo Y, Furukawa Y, Kato T, Miwa N, Nishiwaki T, Kawasoe T, Ishiguro H, Fujita M, Tokino T, Sasaki Y, Imaoka S, Murata M, Shimano T, Yamaoka Y, Nakamura Y (2000b) AXIN1 mutations in hepatocellular carcinomas, and growth suppression in cancer cells by virus-mediated transfer of AXIN1. Nat Genet 24: 245-250

Shimizu Y, Ikeda S, Fujimori M, Kodama S, Nakahara M, Okajima M, Asahara T (2002) Frequent alterations in the Wnt signaling pathway in colorectal cancer with microsatellite instability. Genes Chromosomes Cancer 33: 73-81

Sparks AB, Morin PJ, Vogelstein B, Kinzler KW (1998) Mutational analysis of the APC/beta-catenin/Tcf pathway in colorectal cancer. Cancer Res 58: $1130-1134$

Takamochi K, Ogura T, Suzuki K, Kawasaki H, Kurashima Y, Yokose T, Ochiai A, Nagai K, Nishiwaki Y, Esumi H (2001) Loss of heterozygosity on chromosomes $9 \mathrm{q}$ and $16 \mathrm{p}$ in atypical adenomatous hyperplasia concomitant with adenocarcinoma of the lung. Am J Pathol 159: 1941 1948

Tanaka S, Akiyoshi T, Mori M, Wands JR, Sugimachi K (1998) A novel frizzled gene identified in human esophageal carcinoma mediates APC/ beta-catenin signals. Proc Natl Acad Sci USA 95: $10164-10169$

Taniguchi K, Roberts LR, Aderca IN, Dong X, Qian C, Murphy LM, Nagorney DM, Burgart LJ, Roche PC, Smith DI, Ross JA, Liu W (2002) Mutational spectrum of beta-catenin, AXIN1, and AXIN2 in hepatocellular carcinomas and hepatoblastomas. Oncogene 21: 4863-4871

Tetsu O, McCormick F (1999) Beta-catenin regulates expression of cyclin D1 in colon carcinoma cells. Nature 398: $422-426$

Tilanus HW, Hop WC, Langenhorst BL, van Lanschot JJ (1993) Esophagectomy with or without thoracotomy. Is there any difference? $J$ Thorac Cardiovasc Surg 105: 898-903

Tselepis C, Perry I, Dawson C, Hardy R, Darnton SJ, McConkey C, Stuart RC, Wright N, Harrison R, Jankowski JA (2002) Tumour necrosis factoralpha in Barrett's oesophagus: a potential novel mechanism of action. Oncogene 21: 6071-6081

Van Aken E, De Wever O, Correia da Rocha AS, Mareel M (2001) Defective E-cadherin/catenin complexes in human cancer. Virchows Arch 439: $725-751$

van de Wetering $M$, Barker N, Harkes IC, van der Heyden M, Dijk NJ, Hollestelle A, Klijn JG, Clevers H, Schutte M (2001) Mutant E-cadherin breast cancer cells do not display constitutive Wnt signaling. Cancer Res 61: $278-284$

Washington K, Chiappori A, Hamilton K, Shyr Y, Blanke C, Johnson D, Sawyers J, Beauchamp D (1998) Expression of beta-catenin, alphacatenin, and E-cadherin in Barrett's esophagus and esophageal adenocarcinomas. Mod Pathol 11: $805-813$

Webster MT, Rozycka M, Sara E, Davis E, Smalley M, Young N, Dale TC, Wooster R (2000a) Sequence variants of the axin gene in breast, colon, and other cancers: an analysis of mutations that interfere with GSK3 binding. Genes Chromosomes Cancer 28: $443-453$

Webster MT, Rozycka M, Sara E, Davis E, Smalley M, Young N, Dale TC, Wooster R (2000b) Sequence variants of the axin gene in breast, colon, and other cancers: an analysis of mutations that interfere with GSK3 binding. Genes Chromosomes Cancer 28: $443-453$

Wijnhoven BP, Dinjens WN, Pignatelli M (2000a) E-cadherin-catenin cell - cell adhesion complex and human cancer. Br J Surg 87: 992 - 1005

Wijnhoven BP, Nollet F, De Both NJ, Tilanus HW, Dinjens WN (2000b) Genetic alterations involving exon 3 of the beta-catenin gene do not play a role in adenocarcinomas of the esophagus. Int J Cancer 86: 533-537

Wu R, Zhai Y, Fearon ER, Cho KR (2001) Diverse mechanisms of betacatenin deregulation in ovarian endometrioid adenocarcinomas. Cancer Res 61: $8247-8255$

Yokota N, Nishizawa S, Ohta S, Date H, Sugimura H, Namba H, Maekawa M (2002) Role of Wnt pathway in medulloblastoma oncogenesis. Int J Cancer 101: $198-201$ 